\title{
The Identification of Micro-hydro Power Plants Potential in Irrigation Areas Based on Unmanned Air Vehicle (UAV) Image Processing
}

\author{
Masrur Alatas ${ }^{1, *}$, Maria Theresia Sri Budiastuti ${ }^{2,3}$, Totok Gunawan ${ }^{2,4}$, Prabang Setyono ${ }^{2,5}$, \\ Juris Burlakovs ${ }^{6}$, and Erkata Yandri $^{7}$ \\ ${ }^{1}$ Doctoral Program of Environmental Science, Graduate School of Sebelas Maret University. \\ Jl. Ir. Sutami 36A Surakarta 57126, Central Java, Indonesia \\ ${ }^{2}$ Department of Environmental Science, Graduate School of Sebelas Maret University. \\ Jl. Ir. Sutami 36A Surakarta 57126, Central Java, Indonesia \\ ${ }^{3}$ Department of Agrotechnology, Faculty of Agriculture, Sebelas Maret University. \\ J1. Ir. Sutami 36A Surakarta 57126, Central Java, Indonesia \\ ${ }^{4}$ Faculty of Geography, Universitas Gadjah Mada, Jl. Kaliurang, Bulaksumur, \\ Special Region Yogyakarta 55281, Indonesia \\ ${ }^{5}$ Department of Biological Science, Sebelas Maret University. Jl. Ir. Sutami 36A, \\ Surakarta 57126, Central Java, Indonesia \\ ${ }^{6}$ Department of Water Management, Estonian University of Life Sciences, \\ Friedrich Reinhold Kreutzwaldi 1a, 51014 Tartu, Estonia \\ ${ }^{7}$ Graduate School of Renewable Energy, Darma Persada University, \\ Jl. Taman Malaka Selatan No. 22, Pondok Kelapa, East Jakarta 13450, Indonesia
}

\begin{abstract}
Estimation of the energy demand in Indonesia will increase by $8.15 \%$ annually until 2030. Indonesia is committed to preventing climate change through mix energy (new and renewable energy). One of the sources of this energy is waterpower plants with a potential of $75091 \mathrm{MW}$ have been utilized $6.4 \%$, mini-hydro, and micro-hydro with a potential of $19385 \mathrm{MW}$ have been utilized $1 \%$. In the Industrial Revolution 4.0, it is doable to identify such potential using drone. This study was conducted in the Kalibawang irrigation area, Special Region of Yogyakarta, Indonesia. The procedure starts with the generation of detailed Aerial Photography using Drone DJI Phantom 4. The images from aerial photography were then processed into high-resolution Digital Elevation Model (DEM). DEM data represent the study area topography and can be used to identify the stream gradient potential or height difference $(\mathrm{H})$. Six potential points were identified with height differences between $3 \mathrm{~m}$ to $8 \mathrm{~m}$, resulting in the potential generated power ranging from $125 \mathrm{~kW}$ to $334 \mathrm{~kW}$. This study demonstrates the identification of micro-hydro energy potential points, height difference, and generated power using Drone. Six points were identified with total potential energy $1418 \mathrm{~kW}$.
\end{abstract}

Keywords: alternative energy, cascade, clean energy, digital elevation model, hydropower, irrigation,

\footnotetext{
*Corresponding author: masruralatas@ity.ac.id
} 


\section{Introduction}

The annual population growth rate of Indonesia in this $10 \mathrm{yr}$ is $1.24 \%$. This population growth triggered the growth in the industrial and economic sectors. Therefore, it is estimated that the energy demand in Indonesia will increase by $8.15 \%$ annually until 2030 [1]. National energy demand will steadily increase until 2050, along with economic growth, population growth, energy price, and government policy. Another study by Agency for the Assessment and Application of Technology predicted that with average GDP growth $6.04 \% \mathrm{yr}^{-1}$ and the population growth $0.71 \% \mathrm{yr}^{-1}$ from 2016 to 2050 , it is estimated that the energy demand growth will be $5.3 \% \mathrm{yr}^{-1}$ [2]. Therefore, the energy demand will increase from $795 \times 106$ Barrel of Oil Equivalent (BOE) in 2016 to $4569 \times 10^{6}$ BOE in 2050. In 2050, the highest proportion for energy demand is on petroleum as much as $40.1 \%$, followed by electric $(21.3 \%)$, natural gas $(17.7 \%)$, coal $(11.0 \%)$, and the rest were on LPG, biofuel, and biomass with a percentage below $4 \%$ each.

Fossil fuel, such as coal and petroleum are not only limited and not renewable, and this fuel can also cause climate change and global warming. Many treaties were made to address this problem, such as the United Nations Framework Convention on Climate Change (UNFCCC) on Earth Summit held in Rio de Janeiro, Brazil, in 1992. Kyoto Protocol in Japan in 1997. Bali Road Map on COP 13 in Nusa Dua Bali, Indonesia 2007, COP 17 in Durban, South Africa in 2011, and Paris Agreement in 2015 where the agreement was made to reduce the carbon emission and reduce fossil fuel usage [3]. These treaties have been ratified as Indonesia's commitment to preventing climate change and environmental management.

In order to anticipate energy crisis, stabilize national energy security, and preventing climate change, interdisciplinary government and community working together to increase the renewable energy as sustainable and environmentally friendly energy. One of the potential renewable energy is hydropower plant, especially for mini-hydro and microhydropower plants. There is no clear boundary for mini-hydro and micro-hydropower plants, and their definition can differ between countries. However, in Indonesia, microhydropower plants are the power plant, which can generate up to $1 \mathrm{MW}$ of energy, while mini-hydropower plants have a capacity of $1 \mathrm{MW}$ to $10 \mathrm{MW}$ (Table 1).

Table 1. The classification of hydropower plant (all in MW)

\begin{tabular}{llllllll}
\hline No & Class & Norwegia & Brazil & Turkey & India & Indonesia & Malaysia \\
\hline 1 & Large & - & $>30$ & $>500$ & $>25$ & & $>100$ \\
2 & Medium & - & - & - & - & $>10$ & 10 to 100 \\
3 & Small & 1 to 10 & 1 to 30 & $<500$ & 2.01 to & & 1 to 10 \\
& & & & - & 0.101 to & 1 to 10 & 0.1 to 1 \\
4 & Mini-hydro & - & - & - & 25 & \\
& & & -1 & - & 0.1 & $<1$ & 0.005 to 0.1 \\
5 & Micro-hydro & - & - & - & $<0.1$ & - & $<0.005$ \\
6 & Picohydro & - & - & &
\end{tabular}

Sources: [4-9]

The potential of mini-hydro and micro-hydro power plants can be found in irrigation areas with stable flowrate. A previous study has revealed micro-hydro potential in the Serayu Opak river area with potentially more than $50 \mathrm{~kW}$ [10].

This study demonstrates the identification of micro-hydro energy potential points, height difference $(\mathrm{H})$, and generated power $(\mathrm{P})$ using Unmanned Air Vehicle (UAV) in Kalibawang irrigation area, Special Region of Yogyakarta, Indonesia. 


\section{Method}

\subsection{Study location}

This study was carried out in the Kalibawang irrigation area, Kulonprogo Regency, Special Region of Yogyakarta, Indonesia. Kalibawang Irrigation has an area of 7152 ha [11]. With the inclusion criteria current flow rate of $7000 \mathrm{~L} \mathrm{~s}^{-1}$, and the water should be derived from side intake of the Progo River.

\subsection{Irrigation channel imaging using UAV}

Before irrigation channel identification, a digital map of the irrigation network was obtained from Balai Besar Wilayah Sungai (BBWS) Serayu-Opak, Special Region of Yogyakarta. Then using Google Earth, the initial stream gradient coordinates of irrigation networks were identified, starting from the intake to the primary channel.

The initial stream gradient coordinates were then used for detailed aerial photography using DJI Phantom 4 drone, a UAV with high-resolution data advantage. Another advantage of UAV is that it can produce $3 \mathrm{D}$ photogrammetry at a low cast, and can use even an amateur camera [12]. The flight route and map output scale were prepared and calculated; the flight route was managed using the grid mission model in Pix4D Capture software [13]. Meanwhile, the flight altitude was adjusted to the map scale to acquire accurate information. The flight altitude was adjusted between $50 \mathrm{~m}$ to $75 \mathrm{~m}$ to get the needed scale using the following formula:

$$
S=F /\left(H_{2}-H_{1}\right)
$$

Note: $\mathrm{S}=$ Scale, $\mathrm{F}=$ Camera Focus Length, $\mathrm{H}=$ Flying Height Above Object

\subsection{The identification of micro-hydro potential from aerial image}

The resulting images from aerial photography were then processed into high-resolution Digital Elevation Model (DEM) [14]. DEM data represent the topography of study area, and it can be used to identify the gradient potential in-stream topography, which can be seen by measuring the difference between upper stream surface and lower stream surface or Height difference $(\mathrm{H})$ :

$$
\Delta H=H_{2}-H_{1}
$$

Note: $\mathrm{H}_{2}=$ Upper Water Level, $\mathrm{H}_{1}=$ Lower Water Level

The potential generated power can be measured with Height difference $(\mathrm{H})$ and the stream flow rate $(\mathrm{Q})$ at the primary channel using the following formula:

$$
P=\rho \times g \times H \times Q \times \eta
$$

Note: $\mathrm{P}=$ Power, $\rho=$ specific weight, $\mathrm{g}=$ gravity, $\mathrm{H}=$ Height difference, $\mathrm{Q}=$ Flow rate, $\eta$ $=$ efficiency ratio 


\section{Result and discussion}

The identification result shows six stream gradient points with the potential as micro-hydro power plants. The sites were selected according to the contour map on those six sites, whereas the height differences are between $3 \mathrm{~m}$ to $8 \mathrm{~m}$. Calculation of the power generated using a debit of $5000 \mathrm{~L} \mathrm{~s}^{-1}$ of the existing potential of $7000 \mathrm{~L} \mathrm{~s}^{-1}$, and the goal is to keep the existing channel function properly maintained (Table 1).

Table 2. The site of micro-hydro energy potential point

\begin{tabular}{cccccc}
\hline \multirow{2}{*}{$\begin{array}{c}\text { Stream } \\
\text { Gradient }\end{array}$} & Coordinate & $\begin{array}{c}\text { Flow rate } \\
(\mathrm{Q})\end{array}$ & $\begin{array}{c}\text { Height } \\
\text { Difference } \\
(\Delta \mathrm{H})\end{array}$ & Power (P) \\
\cline { 2 - 6 } & $\mathrm{X}$ & $\mathrm{Y}$ & $\mathrm{m}^{3} \mathrm{~s}^{-1}$ & $\mathrm{~m}$ & $\mathrm{~kW}$ \\
\hline 1 & 418436 & 9150938 & 5 & 7.5 & 313 \\
2 & 416440 & 9148598 & 5 & 5 & 208 \\
3 & 415428 & 9148920 & 5 & 3 & 125 \\
4 & 414409 & 9148102 & 5 & 8 & 334 \\
5 & 412905 & 9147702 & 5 & 7 & 292 \\
6 & 413000 & 9144999 & 5 & 3.5 & 146 \\
\hline
\end{tabular}

The processed data is in the form of Digital Elevation Model (DEM) and the contour line. The DEM data was automatically created through pixel value interpolation using Agisoft Photoscan software. As an example, in point 6, the measurement shows the height difference is $3.5 \mathrm{~m}$. That value was acquired from contour data, which was derived from DEM with interval contour as high as $0.5 \mathrm{~m}$. The amount of electric power potential that can be generated by micro-hydro power plants can be seen in Table 1 . Measurement of the height difference is done for planning and prediction of the energy potential that can be generated, as well as important in determining the type of turbine [15].

The highest power potential located on stream gradient point 4 with theoretical power $334 \mathrm{~kW}$. Stream gradient 1 and 6 as high as $313 \mathrm{~kW}$ and $146 \mathrm{~kW}$, respectively. Point 4 and 5 close to each other with penstock distance $150 \mathrm{~m}$, which can be potentially exploited as Cascade power plants with the total theoretical power $626 \mathrm{~kW}$ with turbine recommendation Vertical Kaplan Turbine can be seen at Figure 1. 


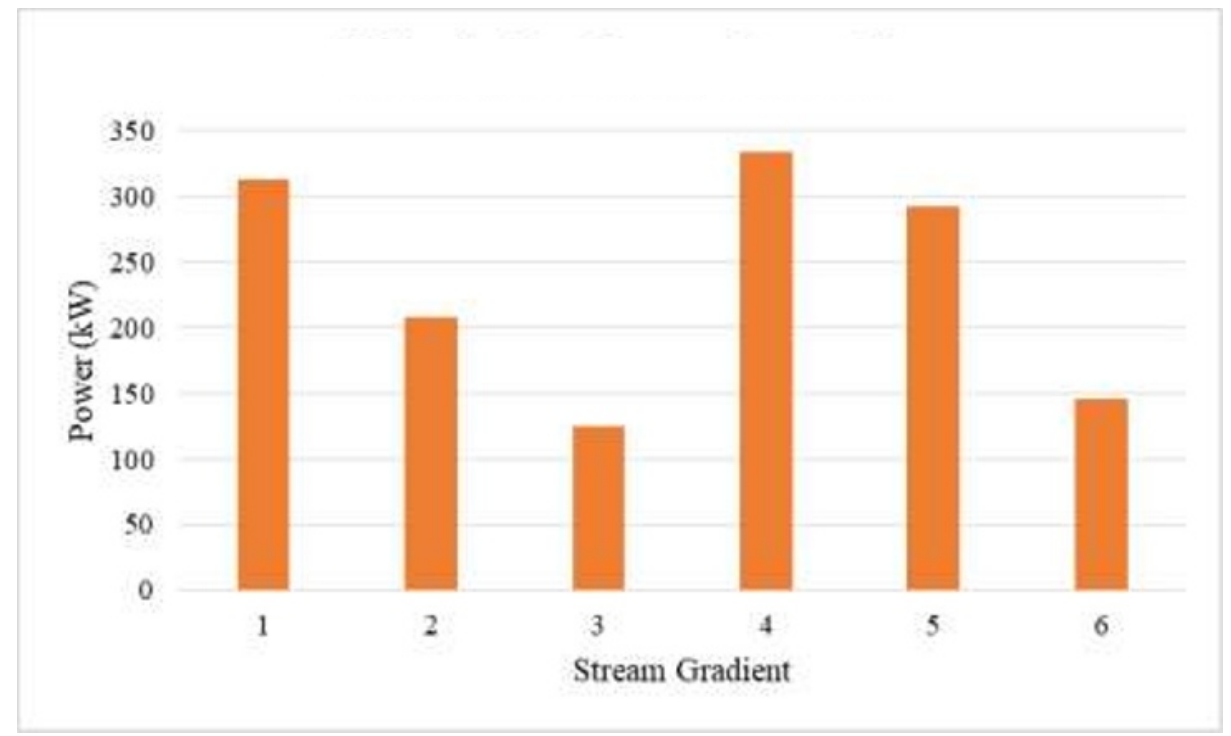

Fig. 1. Micro-hydro Energy Potential

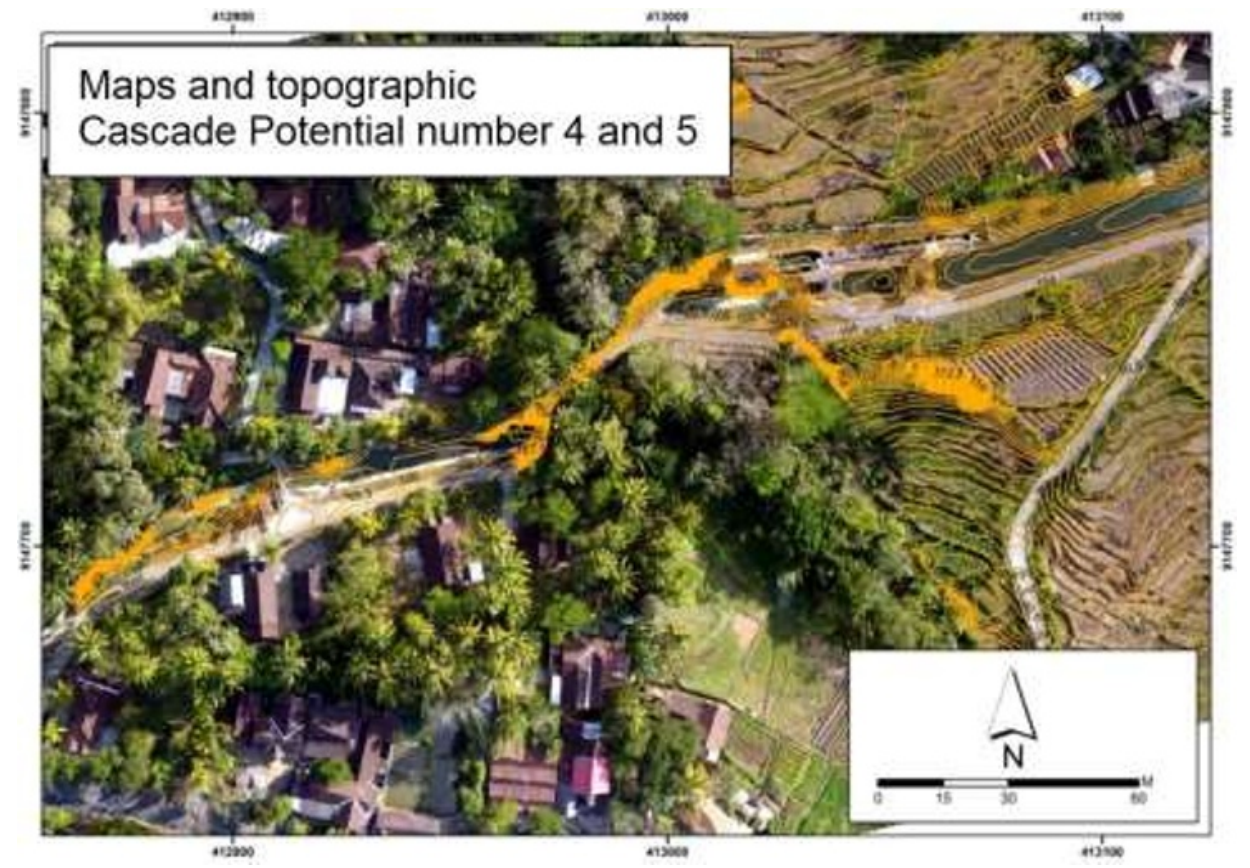

Fig. 2. Cascade Potential number 4 and 5 


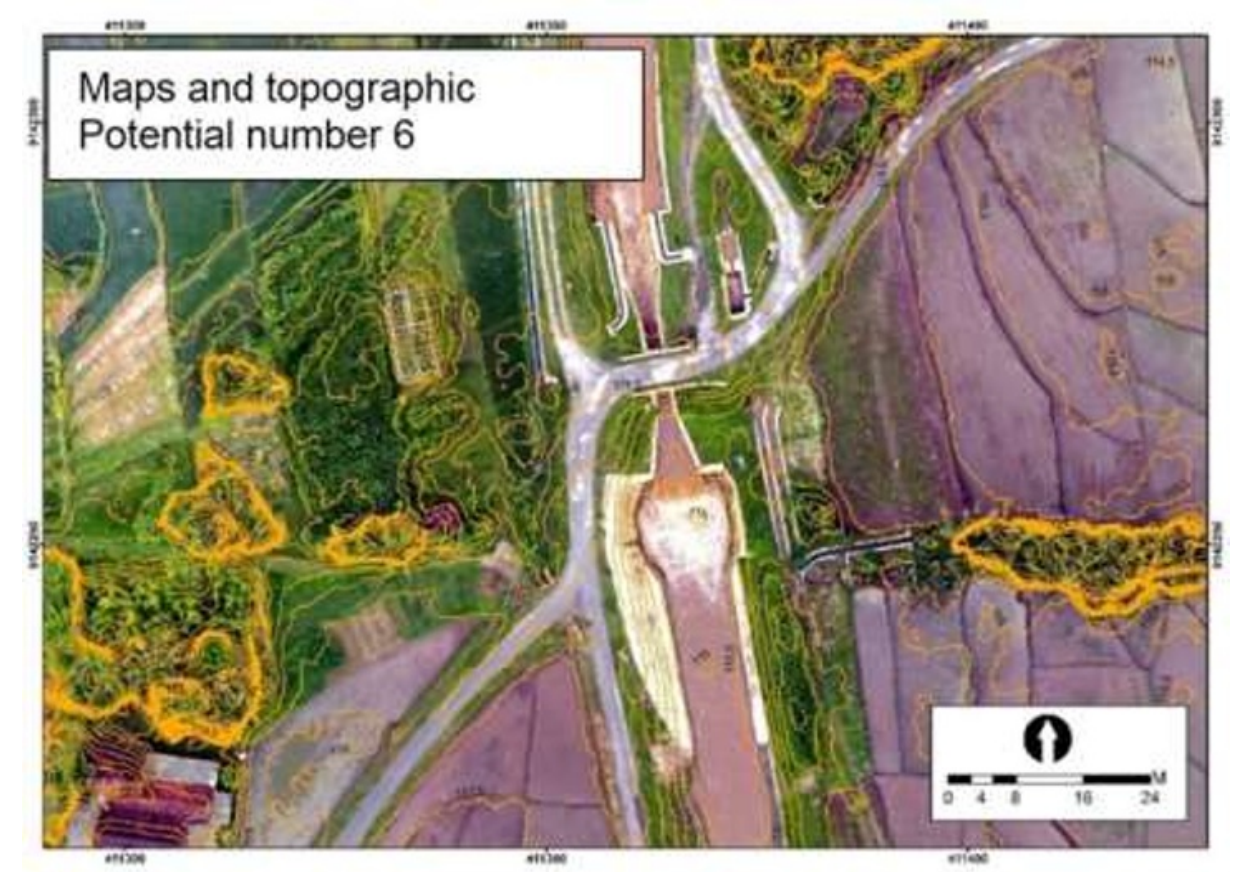

Fig. 3. Potential number 6

\section{Conclusions}

The UAV can be used for the identification of height potential and may reduce the surveyor risk in-field measurement, especially when the channel has a high flow rate and strong current. Based on the identification of the Kalibawang irrigation channel, it is estimated that the channel has a total potential of up to $1418 \mathrm{~kW}$. Among the six points, two points can be exploited as cascade power plants with the total theoretical power $626 \mathrm{~kW}$. It is also recommended to use the Kaplan turbine with a 150 m penstock pipe.

The authors thank to Sebelas Maret University (UNS), Universitas Gadjah Mada (UGM), Komunitas Mikrohidro Terpadu (KMT), Jasa Tirta Energi (JTE) BUMN for the support and cooperation for this research.

\section{References}

1. Pertamina Energy Institute. Pertamina Energy Outlook 2018, [Online] From www.pertamina.com (2018). [Accessed on 30 December 2018]

2. Center for Assessment of Process and Energy Industries, and Agency for the Assessment and Applicatin of Technology, Indonesia Energy Outlook 2018: Sustainable Energy for Land Transportation, [Online] from www.bppt.go.id (2018). [Accessed on 16 December 2018]

3. Setkab. Peraturan Presiden RI, Nomor 22 Tahun 2017 Tentang Rencana Umum Energi Nasional [Republic of Indonesia Presidential Regulation Number 22 of 2017 concerning the National Energy General Plan]. [in Bahasa indonesia]. [Online] from https://sipuu.setkab.go.id/PUUdoc/175146/Perpres\%2022\%20Tahun\%202017.pdf [Accessed on 16 December 2018]. 
4. S.P. Adhau, R.M. Moharil, P.G. Adhau, Renewable and Sustainable Energy Reviews, 16:4785-4795(2012). https://www.doi.org/10.1016/j.rser.2012.03.066

5. T.H. Bakken, H. Sundt, A. Ruud, and A. Harby, Energy Procedia, 20:185-199(2012). https://www.doi.org/10.1016/j.egypro.2012.03.019

6. E.V. Sperling, Energy Procedia, 18:110-118(2012). https://www.doi.org/10.1016/j.egypro.2012.05.023

7. J. Hanafi, A. Riman, Procedia CIRP, 29:444-449(2015) https://www.doi.org/10.1016/j.procir.2015.02.160

8. B. Atilgan, A. Azapagic, Energy Policy, 93:168-186(2016). https://www.doi.org/10.1016/j.enpol.2016.02.055

9. A. Kadier, M.S. Kalil, M. Pudukudy, H.A. Hasan, A. Mohamed, A. A. Hamid, Renewable and Sustainable Energy Reviews, 81:2797-2805(2018) https://www.sciencedirect.com/science/article/abs/pii/S1364032117310249

10. B. Pranoto, S.N. Aini, H. Soekarno, A. Zukhrufiyati, H.A. Rasyid, S. Lestari, Jurnal Irigasi, 12 (2):77-86(2017). [in Bahasa Indonesia]. https://www.doi.org/10.31028/ji.v12.i2.77-86

11. Kemenkumham. Peraturan Menteri Pekerjaan Umum dan Perumahan Rakyat Republik Indonesia No.14/PRT/M/2015 tentang Kriteria dan Penetapan Status Daerah Irigasi [Regulation of the Minister of Public Works and Housing of the Republic of Indonesia No.14 / PRT / M / 2015 concerning Criteria and Determination of Irrigation Area Status]. (in Bahasa Indonesia) http://ditjenpp.kemenkumham.go.id/arsip/bn/2015/bn638-2015.pdf

12. F. Nex, F. Remondino, Applied Geomatics, 6:1-15(2014). https://www.doi.org/10.1007/s12518-013-0120-x

13. E. Akturk, A.O. Altunel, Measurement, 136:382-386(2019). https://www.doi.org/10.1016/j.measurement.2018.12.101

14. S.K. Gupta, D.P. Shukla, Journal of the Indian Society of Remote Sensing, 46,903914(2018). https://www.doi.org/10.1007/s12524-017-0727-1

15. M. Alatas, S. Ediyono, D.E. Putra, Saintis, 9,2:203-210(2017). [in Bahasa Indonesia] http://e-jurnal.unisda.ac.id/index.php/saintis/article/view/1678 